\title{
FAKTOR-FAKTOR YANG BERHUBUNGAN DENGAN KEJADIAN LUKA DEKUBITUS AKIBAT PENGGUNAAN ALAT MEDIS DI RUANG PICU
}

\author{
Rini Angriani ${ }^{1,3 凶}$, Saldy Yusuf ${ }^{2}$, Kadek Ayu Erika ${ }^{2}$, Maryunis $^{3}$ \\ ${ }^{1}$ Program Studi Magister Ilmu Keperawatan Universitas Hasanuddin Makassar \\ ${ }^{2}$ Fakultas Keperawatan Universitas Hasanuddin Makassar \\ ${ }^{3}$ RSUP Dr. Wahidin Sudirohusodo Makassar
}

\begin{tabular}{l} 
ARTICLE INFO \\
\hline Article history \\
Submitted : 2019-08-05 \\
Revised : 2020-12-06 \\
Accepted : 2020-12-28 \\
Keywords: \\
MDRPI \\
Pressure injury \\
Critical conditions \\
Level of awareness
\end{tabular}

Kata Kunci:

MDRPI

Luka dekubitus

Kondisi kritis

Tingkat kesadaran

\begin{abstract}
The use of medical devices in patients treated at the Pediatric Intensive Care Unit (PICU) is very high. Patients who are treated in intensive care are also at risk for medical device-related pressure injury (MDRPI). This study aimed to determine the factors associated with the incidence of MRDPI in the Pediatric Intensive Care Unit (PICU) RSUP DR. Wahidin Sudirohusodo Makassar. This study used an observational analytic method with a prospective cohort approach. The sampling method used a simple random sampling of 76 people. This research was conducted on 8 May - 6 July 2019. The data collection technique used an observation sheet with the research instrument used in the form of the Pediatric Early Warning Scoring System (PEWSS) to assess critical conditions, the level of awareness was fully used Full Outline of UnResponsiveness score (FOUR Score). The data were analyzed by using the statistical test chi-square with a confidence level of $95 \%$. All data were analyzed using the SPSS version 21.0 program (SPSS, Inc. Chicago, IL). Factors associated with the MDRPI incidence include critical conditions based on PEWSS ( $p=0.002)$, level of awareness based on the FOUR Score $(p=0.025)$, number of devices installed $(p=0.015)$, and fixation techniques $(p=0.025)$. As for peripheral tissue perfusion $(p=0.268)$, albumin $(\mathrm{p}=0.309)$, skin moisture $(\mathrm{p}=0.888)$ were not related. Factors associated with the incidence of MDRPI include critical condition, level of awareness, number of devices installed, and fixation techniques. It's recommended to make preventive efforts.

Penggunaan alat kesehatan pada pasien yang dirawat di Pediatric Intensive Care Unit (PICU) sangat tinggi. Pasien yang dirawat dalam perawatan intensif juga sangat berisiko mengalami cedera tekanan terkait perangkat medis (MDRPI). Penelitian ini bertujuan untuk mengetahui faktor-faktor yang berhubungan dengan kejadian MRDPI di Pediatric Intensive Care Unit (PICU) RSUP DR. Wahidin Sudirohusodo Makassar. Penelitian ini menggunakan metode analitik observasional dengan pendekatan kohort prospektif. Pengambilan sampel dengan simple random sampling sebanyak 76 orang. Penelitian ini dilaksanakan pada tanggal 8 Mei -6 Juli 2019. Teknik pengumpulan data menggunakan lembar observasi dengan instrumen penelitian yang digunakan berupa Pediatric Early Warning Scoring System (PEWSS) untuk menilai kondisi kritis, tingkat kesadaran digunakan secara penuh. Full Outline of UnResponsiveness score (FOUR Score). Data diuji dengan uji statistik chi square dengan tingkat kepercayaan $95 \%$. Semua data dianalisis menggunakan program spss versi 21.0 (SPSS, Inc. Chicago, IL). Faktor-faktor yang berhubungan dengan kejadian MDRPI antara lain kondisi kritis berdasarkan PEWSS $(p=0.002)$, level kesadaran berdasarkan FOUR Score $(p=0.025)$, jumlah alat yang dipasang $(\mathrm{p}=0.015)$, dan fiksasi teknik $(\mathrm{p}=0.025)$. Sedangkan perfusi jaringan perifer $(\mathrm{p}=0.268)$, albumin $(\mathrm{p}=0.309)$, kelembaban kulit $(\mathrm{p}=0.888)$ tidak berhubungan. Faktor-faktor yang berhubungan dengan kejadian MDRPI meliputi kondisi kritis, tingkat kesadaran, jumlah perangkat yang dipasang, dan teknik fiksasi. Dianjurkan untuk melakukan upaya preventif..
\end{abstract}

\section{Corresponding Author:}

Rini Angriani

Program Studi Magister Ilmu Keperawatan Universitas Hasanuddin Makassar

Telp. 082194084287

Email: rinimo_ners@yahoo.co.id

\section{PENDAHULUAN}

Setiap tahun di Amerika Serikat, lebih dari 250.000 anak dirawat di Pediatric Intensive
Care Unit (PICU) (Randolph, Gonzales, Cortellini, \& Yeh, 2004). Sedangkan di Indonesia salah satu rumah sakit di Palembang 
sebanyak 219 anak masuk ruang PICU dalam kurun waktu Januari-Juni 2013 (Sari, Iriani, \& Tjekyan, 2013). Sedangkan di RS Dr. Wahidin Sudirohusodo Makassar sebanyak 599 pasien di rawat di Picu selama Januari-Desember 2017, dan sebanyak 318 pasien dalam kurun waktu Januari-Juni 2018, dengan rata-rata LOS (Length Of Stay) 7 hari. Dapat dilihat bahwa jumlah pasien yang di rawat di ruang PICU semakin meningkat.

PICU merupakan tempat khusus untuk manajemen anak-anak dengan penyakit serius dan berat (Ghaffari, Abbaskhanian, \& Nazari, 2014). Penyakit kritis menyiratkan perlunya perangkat medis baik invasif maupun noninvasif yang memerlukan monitoring dan perawatan yang lebih intens (Kudchadkar, Beers, Ascenzi, Jastaniah, \& Punjabi, 2016). Sehingga penggunaan berbagai alat/ perangkat medis di ruang PICU sangat dibutuhkan.

Medical Devices/perangkat medis ditempatkan untuk berbagai indikasi mulai dari pencegahan (misalnya, sequential compression) untuk pengobatan atau terapeutik (misalnya, tubing, drain bedah, enteral feeding tubes, endotracheal intubation tubes) dan untuk diagnostik (misalnya tensimeter, termometer) (Makic, 2015). Kekakuan dan inelastisitas perangkat medis ditambah dengan kesulitan dalam menyesuaikan dan mengamankannya menempatkan kulit di bawah perangkat berisiko terkena iritasi, tekanan, dan kerusakan. Kelembapan dari sekresi, drainase, dan/atau diaforesis di dekat perangkat dapat membuat kulit lebih rentan terhadap cedera (Black, Cuddigan, Walko, Didier, Lander, \& Kelpe, 2010).Maka penggunaan perangkat medis dapat juga menyebabkan cedera kulit dan jaringan seperti luka dekubitus.

Cedera kulit dan jaringan yang diakibatkan oleh penggunaan alat medis yang dikenal dengan istilah Medical Device Related Pressure Injury (MDRPI) (Black \& Kalowes, Medical device-related pressure ulcers, 2016). National Pressure Ulcer Advisory Panel (NPUAP) mendefinisikan MDRPI sebagai ulkus tekanan yang diakibatkan oleh penggunaan perangkat/alat yang dirancang dan diterapkan untuk keperluan diagnostik atau terapeutik (NPUAP, 2013). Tekanan ulkus yang dihasilkan umumnya sesuai dengan pola atau bentuk perangkat. Luka yang terjadi bukan pada area seperti pada luka dekubitus umumnya. Hal ini bisa terjadi pada uretra, telinga, punggung, leher dan lutut, tergantung alat medis yang digunakan (Fletcher J. , 2012). Maka kejadian MDRPI bisa terjadi pada setiap pasien yang menggunakan alat medis secara terus-menerus dan dalam jangka waktu yang lama.

Prevalensi kejadian MDRPI relatif masih terbatas. Dalam penelitian sebelumnya melaporkan sebanyak $1.631(9,1 \%)$ dari 86.932 pasien yang menderita dekubitus (Kayser, VanGilder, Ayello, \& Lachenbruch, 2018). Lokasi yang paling umum adalah telinga (20\%), diikuti oleh daerah sakral/tulang ekor, tumit, dan bokong. Pada tahun 2010, Black dkk. melakukan analisis sekunder terhadap delapan kejadian triwulanan dan studi prevalensi pada 2.079 pasien pusat medis akademis Midwestern. Insiden luka dekubitus secara keseluruhan adalah 5,4\%, dengan MDRPI terjadi di 14 area tubuh, didominasi di telinga (35\%) dan kaki bagian bawah (11\%) dan juga melaporkan bahwa pasien dengan alat medis 2,4 kali lebih mungkin untuk mengalami luka dekubitus (Black, Cuddigan, Walko, Didier, Lander, \& Kelpe, 2010).

Penelitian lain melaporkan prevalensi MDRPI dalam perawatan akut jangka panjang pada 304 fasilitas yang diperoleh luka dekubitus; $44 \%$ berasal dari alat kesehatan. Di antaranya, $14 \%$ ulkus terjadi pada stadium 1, $50 \%$ adalah tahap 2 , dan $36 \%$ adalah tahap 3 pressure ulcer(Long, Ayer, \& Borchert, 2017). Apold dan Rydrych menganalisis 255 pasien pressure injury (Stage 3, Stage 4, atau unstageable), melaporkan bahwa hanya di bawah sepertiga (29\%) dari pressure injury terkait dengan perangkat medis. Jenis perangkat yang terkait dengan pengembangan MDRPI adalah cervical collar (22\%), jenis immobilizer $(17 \%)$, tabung oksigen (13\%), stoking atau sepatu bot (12\%), dan nasogastrik tube ( $8 \%$ ) (Apold \& Rydrych, 2012). Sehingga disimpulkan bahwa prevalensi MDRPI masih cukup tinggi.

Kejadian MDRPI terjadi lebih cepat pada anak-anak dan neonatal karena kulitnya lebih intoleran dan belum matang secara fisiologis. Selain itu, semua bayi, anak-anak dan remaja yang sakit akut dan mengalami imobilitas berisiko mengalami luka dekubitus (Schober-Flores, 2012). Tingkat prevalensi luka dekubitus yang dilaporkan pada bayi, anakanak dan remaja di perawatan akut berkisar antara $7 \%$ sampai $17 \%$ yang meningkat menjadi $27 \%$ untuk yang mengalami sakit kritis 
dan mendapatkan perawatan intensif. Selain kerusakan jaringan terkait dengan imobilitas, sekitar 50\% luka dekubitus pada bayi, anakanak dan remaja berhubungan dengan penggunaan perangkat medis yang menekan atau menggosok pada kulit mereka (Murray, Noonan, Quigley, \& Curley, 2013). Pada tahun 2003, Curley et al menerbitkan data prospektif pertama pada MDR pada anak-anak berusia antara 21 hari dan 8 tahun. Kejadian dekubitus keseluruhan adalah 27\%, dengan $8 \%$ anak mengalami dekubitus akibat penggunaan alat medis. Alat oksigenasi seperti masker tekanan udara, endotrakheal tube (ETT) dan saturasi oksigen merupakan alat yang paling sering mengakibatkan MDRPI yaitu sekitar 74\%(Black \& Kalowes, Medical device-related pressure ulcers, 2016). Di Indonesia kejadian MDRPI dilaporkan oleh Widiati (2018) pada anak usia 1 hari hingga 18 tahun pada 50 responden, alat yang menyebabkan cedera adalah OGT (42\%), Saturasi O2 (6,67\%), dan ETT $(6,67 \%)$. Jadi luka akibat penggunaan alat medis sangat mungkin terjadi terutama pada anak terutama yang dirawat di ruang intensif.

Kejadian luka tekan akibat penggunaan alat medis (MDRPI) di ruang PICU bisa terjadi dengan berbagai penyebab antara lain: karakteristik bahan, kesulitan untuk fiksasi ke tubuh pasien, tekanan dalam jangka waktu lama di tempat yang sama, dan tekanan yang menyebabkan udem lokal (Apold \& Rydrych, 2012). Selain karena kekuatan mekanik alat medis yang bisa menyebabkan perlukaan belum diketahui, fiksasi untuk merekatkan alat ke tubuh pasien juga menimbulkan tekanan dan menyebabkan udem, ditambah dengan perubahan iklim mikro kulit sekitar akibat keringat merupakan faktor lain yang menyebabkan terjadinya perlukaan pada kulit dan jaringan (Black, et al., 2015). Kulit bayi berbeda dari kulit dewasa untuk bayi berusia 1 tahun. Perbedaan ini dalam predisposisi kulit bayi berisiko tinggi mengalami cedera kulit karena kekurangan penghalang kulit yang sehat dan matang (Schober-Flores, 2012). Salah satu perbedaan struktural pada kulit bayi adalah sel kulit lebih kecil dan lebih tipis dari kulit orang dewasa, yang bisa berakibat penghalang bagi lingkungan menjadi lemah. Kulit bayi juga memiliki tingkat penyerapan dan reabsorpsi yang lebih tinggi dibandingkan dengan kulit orang dewasa. Perbedaan ini dalam tingkat penyerapan juga membuat bayi menjadi kering, terkelupas, dan mengalami gangguan kulit (Blume-Peytavi, et al., 2016). Sehingga faktor risiko terjadinya MDRPI pada anak lebih besar terjadi.

Terjadinya perlukaan pada kulit tentu mempunyai dampak buruk, terutama pada anak. Hal yang bisa dialami pasien yang mengalami MDRPI di antaranya nyeri, kehilangan fungsi/kecacatan, dan memungkinkan terjadinya infeksi, sehingga memperpanjang hari rawat dan biaya rumah sakit pun meningkat (Pittman et.al, 2015). Visscher dkk. (2013) menjelaskan bahwa pasien anak merupakan kelompok yang berisiko mengalami luka dekubitus dan mengakibatkan nyeri, risiko infeksi dan perawatan rumah sakit lebih lama. Adanya luka dekubitus yang tidak ditangani dengan baik dapat mengakibatkan masa perawatan pasien menjadi panjang dan peningkatan biaya rumah sakit sehingga membebani ekonomi pasien, lembaga dan masyarakat secara umum terutama pasien yang dirawat di ruang intensif yang memerlukan biaya yang sangat besar(Black, Cuddigan, Walko, Didier, Lander, \& Kelpe, 2010). Sehingga perlu ada upaya untuk mencegah terjadinya MDRPI di ruang intensif.

Perawatan di Pediatric Intensive Care Unit (PICU) adalah ruang khusus untuk merawat pasien kritis khusus anak umur 1 bulan hingga 18 tahun. Pasien yang dirawat merupakan pasien dengan penyakit kritis yang menggunakan berbagai macam alat medis untuk medikasi dan terapi pasien, yang memungkinkan terjadinya luka dekubitus atau MDRPI (Kayser, VanGilder, Ayello, \& Lachenbruch, 2018). Di RSUP DR. Wahidin Sudirohusodo sendiri tersedia ruang PICU yang terdiri dari 12 tempat tidur, dimana pasien berisiko mengalami MDRPI karena menggunakan berbagai macam alat medis. Selama ini kejadian luka akibat penggunaan alat medis ini sering terjadi, namun masih sering luput dari perhatian. Sebagai data awal peneliti melakukan studi kasus selama 7 hari, dan didapatkan 2 kejadian MDRPI dari 11 responden. Ini menunjukkan bahwa MDRPI memang terjadi pada pasien PICU dengan presentasi kejadian sebanyak $18 \%$. Proses terjadinya luka dekubitus ini tentu dipengaruhi oleh banyak hal, dan akibatnya bisa menyebabkan nyeri, infeksi bahkan kecacatan pada pasien. Oleh karena itu peneliti tertarik untuk meneliti faktor yang berhubungan dengan 
kejadian dekubitus akibat penggunaan alat medis (MDRPI) di Ruang PICU RSUP Dr. Wahidin Sudirohusodo Makassar.

\section{METODE PENELITIAN Jenis Penelitian}

Jenis penelitian yang digunakan adalah analitik observasional dengan menggunakan pendekatan Cohort Prospective. Subjek penelitian di observasi setiap hari tentang kondisi pasien dan alat yang digunakan. Setiap 3 hari atau pada saat penggantian fiksasi, dilakukan observasi kulit sekitar alat dengan mengecek kelembapan dan suhu, serta melihat adanya luka dekubitus.

Observasi dilakukan pada subjek dengan perawatan minimal 3 hari dan maksimal 15 hari perawatan. Penelitian ini bertujuan untuk mengetahui faktor risiko kejadian luka dekubitus akibat penggunaan alat medis di ruang PICU RSUP Dr. Wahidin Sudirohusodo Makassar.

\section{Lokasi dan Waktu Penelitian}

Penelitian ini dilakukan di Ruang PICU RSUP Dr. Wahidin Sudirohusodo Makassar dari tanggal 8 Mei - 6 Juli 2019.

\section{Populasi dan Sampel}

Populasi penelitian ini adalah seluruh pasien yang dirawat di ruang PICU RSUP Dr. Wahidin Sudirohusodo Makassar dengan ratarata per bulan 50 orang dengan jumlah pasien baru rata-rata sebanyak 45 orang. Maka perkiraan besarnya populasi yang akan diteliti selama observasi 2 bulan adalah 90 orang.

Pengambilan sampel menggunakan teknik probability sampling dengan pendekatan simple random sampling (Sugiyono, 2013). Dengan menggunakan rumus slovin, jumlah sampel yang dibutuhkan sebanyak 74 orang $(\mathrm{n}=73,47)$. Namun selama 2 bulan penelitian didapatkan sampel sebanyak 76 orang.

\section{Pengumpulan Data}

Pengumpulan data akan dilakukan dengan menggunakan lembar observasi, alat tulis dan kamera digital, kamera infra merah dan alat moisture checker untuk mengumpulkan data tentang faktor risiko kejadian luka dekubitus akibat penggunaan alat medis di PICU RSUP Wahidin Sudirohusodo Makassar. Untuk menilai kondisi kritis digunakan Pediatric Early Warning Scoring System
(PEWSS), tingkat kesadaran di gunakan Full Outline of UnResponsiveness score (FOUR score) dan evaluasi risiko kami akan menggunakan Braden QD scale (Curley, et al., 2018.

Penelitian ini telah mendapatkan persetujuan etik dari Komisi Etik Penelitian Kedokteran dan Kesehatan Universitas Hasanuddin Makassar.

\section{Pengolahan dan Analisis Data}

Data diuji dengan uji statistik Chi Square Test dengan tingkat kepercayaan 95\%. Semua data dianalisis dengan program SPSS versi 21,0 (SPSS, Inc Chicago, IL).

\section{HASIL PENELITIAN}

Berdasarkan Tabel 1 tentang karakteristik responden di Ruang PICU RSUP Dr. Wahidin Sudirohusodo Makassar menunjukkan bahwa dari 76 orang responden ditemukan responden berjenis kelamin laki-laki lebih banyak dari perempuan dengan usia ratarata 2,11 tahun. Sedangkan diagnosa utama terbanyak adalah pasien dengan post operasi dan disertai 1 diagnosa sekunder.

Tabel 1. Karakteristik Responden Ruang PICU RSUP Dr. Wahidin Sudirohusodo Makassar

\begin{tabular}{lccc}
\hline \multicolumn{1}{c}{ Karakteristik } & n & \% & Mean \pm SD \\
\hline Umur (Tahun) & 76 & 100 & $2.11 \pm 1.04$ \\
Lama rawat & 76 & 100 & $5.17 \pm 4.09$ \\
Jenis Kelamin & & & \\
Laki-laki & 42 & 55.3 & \\
Perempuan & 34 & 44.7 & \\
Diagnosa Utama & 76 & 100 & \\
Post operasi & 25 & 32.9 & \\
Encepalopaty & 22 & 28.9 & \\
CAP/PJB & 13 & 17.1 & \\
AKI & 6 & 7.9 & \\
Sepsis & 5 & 6.6 & \\
Tumor & 3 & 3.9 & \\
DBD & 2 & 2.6 & \\
Diagnosa Sekunder & 76 & 100 & \\
\hline
\end{tabular}

Tabel 2 tentang variabel penelitian di Ruang PICU RSUP Dr. Wahidin Sudirohusodo Makassar menunjukkan gambaran responden sebagian besar berisiko tinggi mengalami dekubitus, dengan kriteria kondisi kritis berdasarkan PEWSS berada pada kode hijau/kuning, serta mengalami penurunan tingkat kesadaran berdasarkan FOUR Score. 
Namun dari segi perfusi jaringan, kadar hemoglobin, tekanan darah, pengisian kapiler, Saturasi $\mathrm{O}_{2}$, serta kadar albumin sebagian besar masih dalam batas normal. Sedangkan kelembapan kulit, responden cenderung mengalami kulit kering. Responden juga menggunakan alat medis yang banyak (lebih dari 5 alat) disertai dengan teknik fiksasi yang kurang tepat.

Tabel 2. Gambaran Hasil Pemeriksaan Responden berdasarkan Variabel Penelitian di Ruang PICU RSUP Dr. Wahidin Sudirohusodo Makassar

\begin{tabular}{|c|c|c|}
\hline Variabel & $\mathbf{n}$ & $\%$ \\
\hline \multicolumn{3}{|l|}{ Risiko Dekubitus } \\
\hline Berisiko $(\geq 13)$ & 40 & 52.6 \\
\hline Tidak berisiko $(<13)$ & 36 & 47.4 \\
\hline \multicolumn{3}{|l|}{ Kondisi Kritis (PEWSS) } \\
\hline Hijau/Kuning & 47 & 68,1 \\
\hline Oranye/Merah & 29 & 38,2 \\
\hline \multicolumn{3}{|l|}{ Kesadaran (FOUR Score) } \\
\hline Ada & 42 & 55,3 \\
\hline Tidak Ada & 34 & 44,7 \\
\hline \multicolumn{3}{|l|}{ Perfusi Jaringan } \\
\hline Adekuat & 40 & 52,6 \\
\hline Tidak Adekuat & 36 & 47,4 \\
\hline \multicolumn{3}{|l|}{ Kadar Hemoglobin } \\
\hline Normal & 45 & 59,2 \\
\hline Rendah & 31 & 40,8 \\
\hline \multicolumn{3}{|l|}{ Tekanan Darah } \\
\hline Normal & 70 & 92,1 \\
\hline Rendah & 6 & 7,9 \\
\hline \multicolumn{3}{|l|}{ Pengisian Kapiler } \\
\hline Normal & 64 & 84,2 \\
\hline Rendah & 12 & 15,8 \\
\hline \multicolumn{3}{|l|}{ Saturasi O2 } \\
\hline Normal & 73 & 96,1 \\
\hline Rendah & 3 & 3,9 \\
\hline \multicolumn{3}{|l|}{ Kadar Albumin } \\
\hline Normal & 48 & 63,2 \\
\hline Kurang & 28 & 36,8 \\
\hline \multicolumn{3}{|l|}{ Kelembapan Kulit } \\
\hline Kering & 49 & 64,5 \\
\hline Normal & 26 & 34,2 \\
\hline Lembap & 1 & 1,3 \\
\hline \multicolumn{3}{|l|}{ Jumlah Alat Terpasang } \\
\hline Sedikit $(<5)$ & 20 & 26,3 \\
\hline Banyak $(\geq 5)$ & 56 & 73,7 \\
\hline \multicolumn{3}{|l|}{ Teknik Fiksasi } \\
\hline Tepat & 34 & 44,7 \\
\hline Tidak Tepat & 42 & 55,3 \\
\hline
\end{tabular}

Tabel 3 tentang Kejadian Dekubitus MDRPI di Ruang PICU RSUP Dr. Wahidin Sudirohusodo Makassar menunjukkan bahwa responden yang mengalami MDRPI sebanyak 14 orang $(18,4 \%)$ dengan waktu kejadian terbanyak di hari ke-3, serta mengalami luka dekubitus tertinggi adalah derajat 1. Adapun alat medis yang menyebabkan MDRPI meliputi Endotracheal Tube (ETT), Non-Rebreathing Mask (NRM), dan Saturasi $\mathrm{O}_{2}$.

\section{Tabel 3. Gambaran Hasil Pemeriksaan Responden berdasarkan Kejadian MDRPI di Ruang PICU RSUP Dr. Wahidin Sudirohusodo Makassar}

\begin{tabular}{lcc}
\hline \multicolumn{1}{c}{ MRDPI } & n & \% \\
\hline Kejadian & & \\
Tidak & 62 & 81,6 \\
Ya & 14 & 18,4 \\
Waktu Kejadian & & \\
Tidak & 62 & 81,6 \\
Hari ke-1 & 3 & 3,9 \\
Hari ke-3 & 7 & 9,2 \\
Hari ke-6 & 4 & 5,3 \\
Hari ke-9 & 0 & 0 \\
Hari ke-12 & 0 & 0 \\
Hari ke-15 & 0 & 0 \\
Derajat & & \\
Tidak & 62 & 81,6 \\
Derajat 1 & 12 & 15,8 \\
Derajat 2 & 2 & 2,6 \\
Penyebab & & \\
Tidak & 62 & 81,6 \\
ETT & 9 & 11,8 \\
NRM & 3 & 3,9 \\
Saturasi O2 & 2 & 2,6 \\
\hline
\end{tabular}

Tabel 4 tentang faktor risiko kejadian luka dekubitus akibat penggunaan alat medis menunjukkan bahwa risiko dikubitus, kondisi kritis $(\mathrm{p}=0,002)$, penurunan kesadaran berdasarkan FOUR score $(\mathrm{p}=0,025)$, jumlah alat terpasang $(\mathrm{p}=0,015)$, dan teknik fiksasi alat $(\mathrm{p}=0,025)$ berhubungan dengan kejadian dekubitus MDRPI di Ruang PICU RSUP Dr. Wahidin Sudirohusodo Makassar. Adapun perfusi jaringan, kadar hemoglobin, tekanan darah, CRT/ pengisian kapiler, saturasi oksigen $\left(\mathrm{SpO}_{2}\right)$, kadar albumin, dan kelembapan kulit tidak berhubungan dengan kejadian dekubitus MDRPI ( $p>0,05)$. 
Tabel 4. Faktor Risiko Kejadian Luka Dekubitus Akibat Penggunaan Alat Medis (MDRPI) di Ruang PICU RSUP Dr. Wahidin Sudirohusodo Makassar

\begin{tabular}{|c|c|c|c|c|c|}
\hline \multirow{3}{*}{ Variabel } & \multicolumn{4}{|c|}{ MRDPI } & \multirow{3}{*}{$\mathbf{p}$} \\
\hline & \multicolumn{2}{|c|}{ Tidak } & \multicolumn{2}{|c|}{$\mathbf{Y a}$} & \\
\hline & $\mathbf{n}$ & $\%$ & n & $\%$ & \\
\hline Risiko Dekubitus & & & & & \multirow{3}{*}{0,002} \\
\hline$\geq 13$ & 27 & 65,7 & 13 & 32,5 & \\
\hline$<13$ & 35 & 97,2 & 1 & 2,8 & \\
\hline \multicolumn{6}{|l|}{ Kondisi Kritis } \\
\hline Hijau/Kuning & 44 & 93,6 & 3 & 6,4 & \multirow[t]{2}{*}{0,002} \\
\hline Oranye/Merah & 18 & 62,1 & 11 & 37,9 & \\
\hline \multicolumn{6}{|l|}{ Kesadaran } \\
\hline Ada & 30 & 71,4 & 12 & 28,6 & \multirow[t]{2}{*}{0,025} \\
\hline Tidak Ada & 32 & 94,1 & 2 & 5,9 & \\
\hline \multicolumn{6}{|l|}{ Perfusi Jaringan } \\
\hline Adekuat & 35 & 87,5 & 5 & 12,5 & \multirow[t]{2}{*}{0,268} \\
\hline Tidak Adekuat & 27 & 75,0 & 9 & 25,0 & \\
\hline \multicolumn{6}{|l|}{ Kadar Hemoglobin } \\
\hline Normal & 37 & 82,2 & 8 & 17,8 & \multirow[t]{2}{*}{1,000} \\
\hline Rendah & 25 & 80,6 & 6 & 19,4 & \\
\hline \multicolumn{6}{|l|}{ Tekanan Darah } \\
\hline Normal & 57 & 81,4 & 13 & 18,6 & \multirow[t]{2}{*}{1,000} \\
\hline Rendah & 5 & 83,3 & 1 & 16,7 & \\
\hline \multicolumn{6}{|l|}{ Pengisian Kapiler } \\
\hline Normal & 53 & 82,8 & 11 & 17,2 & \multirow[t]{2}{*}{0,685} \\
\hline Rendah & 9 & 75,0 & 3 & 25,0 & \\
\hline \multicolumn{6}{|l|}{ Saturasi O2 } \\
\hline Normal & 60 & 82,2 & 13 & 17,8 & \multirow[t]{2}{*}{0,462} \\
\hline Rendah & 2 & 88,7 & 1 & 33,3 & \\
\hline \multicolumn{6}{|l|}{ Kadar Albumin } \\
\hline Normal & 37 & 77,1 & 11 & 22,9 & \multirow[t]{2}{*}{0,309} \\
\hline Kurang & 25 & 89,3 & 3 & 10,7 & \\
\hline \multicolumn{6}{|l|}{ Kelembapan } \\
\hline Kering & 40 & 81,6 & 9 & 18,4 & \multirow{3}{*}{0,888} \\
\hline Normal & 21 & 80,8 & 5 & 19,2 & \\
\hline Lembap & 1 & 100 & 0 & 0 & \\
\hline \multicolumn{6}{|l|}{ Jumlah Alat } \\
\hline Sedikit $(<5)$ & 20 & 100 & 0 & 0 & \multirow[t]{2}{*}{0,015} \\
\hline Banyak ( $\geq 5)$ & 42 & 75,0 & 14 & 25,0 & \\
\hline Teknik Fiksasi & & & & & \\
\hline Tepat & 32 & 94,1 & 2 & 5,9 & 0,025 \\
\hline Tidak Tepat & 30 & 71,4 & 12 & 28,6 & \\
\hline
\end{tabular}

\section{PEMBAHASAN}

Hubungan antara kondisi kritis pasien dengan kejadian luka dekubitus akibat penggunaan alat medis

Hasil penelitian ini didapatkan kondisi kritis berdasarkan PEWSS berhubungan dengan kejadian MDRPI di Ruang PICU RSUP Dr.
Wahidin Sudirohusodo Makassar. Kondisi kritis pasien yang ditentukan dengan PEWSS dengan mengelompokkan skoring menjadi 4 warna, yaitu hijau, kuning, oranye, dan merah. Semua pasien yang mengalami luka dekubitus berada di kelompok oranye atau merah, dimana pasien memerlukan penanganan khusus untuk 
penanganan kondisi agar tidak semakin memburuk. Karena petugas berfokus pada perbaikan kondisi pasien, maka upaya untuk mencegah dekubitus dikesampingkan sampai kondisi kritis teratasi. Sehingga jika pasien tidak mengalami perbaikan kondisi, sangat berisiko mengalami luka dekubitus baik MDRPI maupun non-MDRPI.

Hasil penelitian ini sejalan dengan penelitian Schober-Flores (2012), yang menemukan bahwa luka dekubitus yang dilaporkan pada bayi, anak-anak dan remaja di perawatan akut akan meningkat menjadi pada yang mengalami sakit kritis dan mendapatkan perawatan intensif. Pasien dengan kondisi kritis memerlukan beberapa peralatan medis, meningkatkan risiko mereka mengalami MDRPI. Selain itu, mereka mendapat obat bius dan tidak dapat merasakan tekanan dari peralatan yang digunakan atau untuk memberitahukan tentang ketidaknyamanannya. Pasien yang sakit kritis mungkin juga terlalu lemah untuk memosisikan diri untuk menghindari tekanan dari alat medis (Lerner, 2014).

Disimpulkan bahwa pasien dengan kondisi kritis berdasarkan PEWSS kategori oranye atau merah lebih berisiko mengalami dekubitus MDRPI dibandingkan dengan pasien yang PEWSS-nya kategori hijau atau kuning.

\section{Hubungan antara penurunan kesadaran pada pasien dengan kejadian luka dekubitus akibat penggunaan alat medis}

Hasil penelitian ini didapatkan
kesadaran berdasarkan FOUR score
berhubungan dengan kejadian dekubitus MDRPI di Ruang PICU RSUP Dr. Wahidin Sudirohusodo Makassar. Dalam penelitian ini di dapatkan semua pasien yang mengalami luka dekubitus mengalami penurunan kesadaran. Penurunan kesadaran dinilai dari respon mata, respon motorik, refleks brainstem, dan pernapasan. Beberapa pasien dengan diagnosa gangguan neurologi adalah yang banyak mengalami penurunan kesadaran, bisa berlangsung sesaat ataupun sampai beberapa hari. Selain itu pasien dengan gangguan pernapasan menyebabkan pasien gelisah, dan apabila anoksia berlangsung lama dapat menyebabkan penurunan kesadaran. Ada pun pasien yang terintubasi baik post operasi maupun karena indikasi gagal napas, kesadarannya juga menurun karena mendapatkan sedasi.

Hasil penelitian ini sejalan dengan penelitian Black J (2013) menemukan bahwa risiko tertinggi kejadian MDRPI yang dilaporkan adalah pasien dengan gangguan persepsi sensori, seperti neuropati, dan terganggunya kemampuan pasien untuk mengungkapkan ketidaknyamanannya, seperti pasien dengan intubasi oral, kendala bahasa, pasien tidak sadar. Adanya penurunan persepsi sensori menyebabkan pasien tidak mampu mendeteksi adanya nyeri atau tekanan pada bagian tubuhnya. Setiap pasien yang tidak dapat merasakan tekanan misalnya pasien yang dibius, tersedasi, lumpuh, atau mengalami disfungsi sistem motorik dan sensorik paling berisiko. Tanpa kewaspadaan perawat tekanan alat medis dapat menyebabkan kerusakan jaringan. Ini dapat terjadi dengan cepat dan menjadi parah, terutama jika alat medis terletak di atas tulang atau daerah tulang rawan seperti hidung, telinga, atau mata kaki.

Disimpulkan bahwa pasien dengan kesadaran berdasarkan FOUR Score yang rendah lebih berisiko mengalami dekubitus MDRPI dan non-MDRPI dibandingkan dengan pasien yang FOUR Score-nya tinggi.

Hubungan antara perfusi jaringan perifer dengan kejadian luka dekubitus akibat penggunaan alat medis

Hasil penelitian ini didapatkan perfusi jaringan perifer termasuk hemoglobin, tekanan darah sistole, tekanan darah diastole, CRT dan $\mathrm{SpO}_{2}$ tidak berhubungan dengan kejadian dekubitus MDRPI di Ruang PICU RSUP Dr. Wahidin Sudirohusodo Makassar. Ketika keadaan kulit yang sudah berisiko mengalami luka dekubitus, ditambah adanya tekanan pada kulit dengan perfusi jaringan subkutan yang tidak adekuat, luka dekubitus dapat mulai terbentuk hanya dalam 2 jam (Lyder dan Ayello, 2012). Dan akan meningkatkan risiko 2 hingga 4 kali dengan penggunaan alat medis (Black, 2013). Sebagian besar responden yang mengalami MDRPI mengalami gangguan perfusi jaringan perifer. Namun ada pula yang tidak mengalami gangguan perfusi jaringan namun tetap mengalami luka dekubitus, ini dikarenakan mereka mengalami penurunan kesadaran atau pun responden yang sadar namun masih bayi yang tidak mampu 
mengungkapkan ketidak-nyamanannya secara langsung.

Selain itu, gangguan perfusi jaringan perifer cenderung lebih mudah diatasi dengan terapi yang cepat dan tepat. Seperti ketika pasien mengalami penurunan tekanan darah dan pengisian kapiler memanjang (CRT>3 detik), serta penurunan kadar hemoglobin, maka segera diberikan terapi cairan, transfusi darah atau obat-obatan vasopresor. Secara umum akan mengalami perbaikan segera dalam beberapa menit atau beberapa jam kemudian setelah terapi diberikan. Namun ada beberapa responden yang perfusi jaringan perifernya tidak adekuat hingga beberapa hari, sehingga meningkatkan risiko terjadinya MDRPI.

Meskipun secara statistik tidak ditemukan hubungan yang bermakna antara perfusi jaringan perifer dengan kejadian dekubitus MDRPI, tetapi dari segi persentase didapatkan pasien yang mengalami dekubitus lebih banyak yang perfusi jaringannya tidak adekuat dibandingkan dengan yang adekuat. Hal ini menunjukkan adanya kecenderungan pasien yang perfusi jaringannya tidak adekuat lebih berisiko mengalami dekubitus MDRPI dibandingkan dengan pasien yang perfusi jaringannya adekuat.

\section{Hubungan antara kadar albumin dengan kejadian luka dekubitus akibat penggunaan alat medis}

Hasil penelitian ini didapatkan kadar albumin tidak berhubungan dengan kejadian dekubitus MDRPI di Ruang PICU RSUP Dr. Wahidin Sudirohusodo Makassar. Karena kekurangan kadar albumin dapat dikoreksi segera dengan melakukan transfusi albumin. Selain itu juga dilakukan upaya lain untuk memperbaiki status nutrisi responden yaitu dengan memberikan asupan nutrisi secara enteral maupun parenteral. Untuk mencegah terjadinya mallnutrisi yang masif. Sehingga dapat mengurangi risiko terjadinya luka dekubitus.

Menurut penelitian Hansen \& Fossum (2016) hipoalbuminemia, kehilangan berat badan, dan malnutrisi umumnya diidentifikasi sebagai faktor predisposisi untuk terjadinya luka dekubitus. Pasien dengan sakit kronis biasanya asupan nutrisinya juga tidak adekuat. Diperkirakan $15 \%$ hingga $20 \%$ pasien yang dirawat di PICU mengalami malnutrisi (Baharestani \& Ratliff, 2007). Didapatkan anak yang dirawat di rumah sakit dengan luka dekubitus, tidak ada yang ditemukan menerima nutrisi yang adekuat. Efek sistemik dan imunologis malnutrisi pada anak dengan sakit kronis semakin membatasi toleransi jaringan mereka terhadap tekanan, gaya gesekan, dan shear, terutama karena mengalami hipoalbuminemia.

Meskipun dalam penelitian ini tidak ditemukan hubungan antara kadar albumin dengan kejadian MDRPI. Upaya pemenuhan nutrisi pasien kritis tetap perlu dilakukan untuk mencegah semakin memberatnya penyakit dasar maupun komplikasinya.

\section{Hubungan antara kelembapan kulit dengan kejadian luka dekubitus akibat penggunaan alat medis}

Hasil penelitian ini didapatkan kelembapan kulit tidak berhubungan dengan kejadian dekubitus MDRPI di Ruang PICU RSUP Dr. Wahidin Sudirohusodo Makassar. Sebagian besar responden memiliki kulit kering yang diukur dengan menggunakan Moisture Checker. Adanya perbedaan karakteristik kulit dan suhu lingkungan mempengaruhi kelembapan kulit responden. Namun hasil yang didapatkan merupakan hasil rata-rata tingkat kelembapan kulit di sekitar pemasangan alat. Sehingga ada tempat yang terlalu lembap seperti bibir, namun tidak terdata. Sudut bibir merupakan lokasi terjadinya MDRPI terbanyak akibat penggunaan ETT. Kelembapan kulit karena keringat atau sekresi di bawah alat medis dapat membuat kulit menjadi maserasi, membuatnya rentan terhadap pembentukan luka dekubitus. Kelembapan mungkin merupakan kofaktor untuk perkembangan luka, membuat kulit kurang kenyal dengan adanya sekresi atau penyebab kelembapan lainnya (Black, et al., 2015).

Lokasi terjadinya MDRPI banyak terjadi di daerah yang lembap seperti bibir, dan kulit yang sangat kering. Selain itu bahan dari alat yang digunakan sebagian besar terbuat dari karet yang menyebabkan kulit dibawahnya menyekresi keringat akibatnya kulit menjadi lembap.

Hubungan antara jumlah alat yang digunakan pasien dengan kejadian luka dekubitus akibat penggunaan alat medis

Hasil penelitian ini didapatkan jumlah alat terpasang berhubungan dengan kejadian 
dekubitus MDRPI di Ruang PICU RSUP Dr. Wahidin Sudirohusodo Makassar. Didapatkan responden yang mengalami MDRPI adalah yang menggunakan alat medis yang banyak yaitu lebih dari 5 alat yang berbeda. Masingmasing alat tersebut mempunyai fungsi yang berbeda pula yang digunakan untuk keperluan diagnostik maupun terapeutik. Alat untuk keperluan diagnostik meliputi elektroda, saturasi O2, tensimeter, suhu monitor. Adapun alat yang digunakan untuk keperluan terapeutik yang paling banyak digunakan adalah Endotracheal Tube, $\mathrm{O} 2$ Non Rebreathing Mask, $\mathrm{O} 2$ sungkup, $\mathrm{O} 2$ binasal kanul, oropharingeal tube, Nasogastric Tube (NGT), serta Intra Vena (IV) Catheter. Alat yang paling banyak digunakan adalah alat oksigenasi merupakan alat yang sangat penting untuk mengatasi gagal napas. Selain itu responden juga semua menggunakan IV kateter untuk terapi obat dan cairan. Serta penggunaan NGT/OGT untuk intake nutrisi. Banyaknya alat yang terpasang membuat gerakan pasien menjadi terbatas, dan tidak mampu untuk mengidentifikasi ketidaknyamanannya (Curley et al, 2017).

Disimpulkan bahwa pasien dengan jumlah alat yang terpasang banyak lebih berisiko mengalami dekubitus MDRPI dibandingkan dengan pasien yang jumlah alat yang terpasang sedikit.

\section{Hubungan antara teknik fiksasi alat dengan kejadian luka dekubitus akibat penggunaan alat medis}

Hasil penelitian ini didapatkan teknik fiksasi alat berhubungan dengan kejadian dekubitus MDRPI di Ruang PICU RSUP Dr. Wahidin Sudirohusodo Makassar. Teknik fiksasi yang ideal yaitu tidak menyebabkan kulit keriput atau terjepit, tidak pada tonjolan tulang, serta mudah direposisi. Namun tidak semua alat yang digunakan tidak dapat difiksasi dengan baik. Pemasangan plaster fiksasi yang tidak hati-hati bisa menyebabkan kulit berkerut dan terjepit, yang bisa menyebabkan aliran darah ke daerah tersebut terhambat. Selain itu, ada beberapa alat yang tidak mudah untuk direposisi, seperti endotracheal tube (ETT) karena bisa tercabut, serta rata-rata pemakaian dalam jangka waktu lama dan penekanan di area tersebut secara terus-menerus menyebabkan terjadinya MDRPI.

Fiksasi diperlukan untuk mengamankan peralatan medis untuk mencegah pergeseran.
Namun, bagaimanapun juga, ini harus dilakukan tanpa menciptakan tekanan tambahan pada jaringan sekitarnya. Tabung nasogastrik dan endotrakeal sering dikaitkan dengan kerusakan sebagai akibat dari teknik fiksasinya (McNichol, Lund, Rosen, \& Gray, 2013). Meskipun perekat ini efektif dalam memfiksasi alat, penerapannya dapat menyebabkan ketegangan pada jaringan di sekitarnya, meningkatkan gesekan dan menyebabkan tekanan dari peralatan ke kulit yang berdekatan (Mohammed \& Hassan, 2015). Teknik fiksasi yang tepat diharapkan mampu mengamankan alat medis namun tidak menimbulkan tekanan pada kulit. Hal ini sangat sulit dilakukan,

Disimpulkan bahwa pasien dengan teknik fiksasi alat yang tidak sesuai lebih berisiko mengalami dekubitus MDRPI dibandingkan dengan pasien yang teknik fiksasi alatnya sesuai.

\section{KESIMPULAN DAN SARAN}

Pasien anak yang dirawat di ruang intensif berisiko tinggi mengalami dekubitus akibat penggunaan alat medis (MDRPI). Faktor yang berhubungan adalah adanya kondisi kritis berdasarkan PEWSS, penurunan kesadaran berdasarkan FOUR Score, jumlah alat yang terpasang, serta teknik fiksasi alat yang digunakan. Adapun faktor lain yaitu perfusi jaringan perifer (meliputi kadar hemoglobin, tekanan darah, dan pengisian kapiler), kadar albumin serta kelembapan kulit tidak memberikan pengaruh secara signifikan terhadap kejadian MDRPI.

Diharapkan kepada pihak rumah sakit agar memberikan perhatian yang lebih terkait dengan luka dekubitus akibat penggunaan alat medis dengan memasukkannya sebagai salah satu indikator mutu rumah sakit sehingga dapat dinilai secara berkelanjutan. Diharapkan kepada perawat untuk memperhatikan faktor risiko yang lebih terkait dengan luka dekubitus akibat penggunaan alat medis sehingga kejadian MDRPI dapat diminimalisir. Diharapkan kepada peneliti selanjutnya untuk melakukan penelitian dengan menilai hubungan dekubitus akibat penggunaan alat medis dengan lama perawatan dan outcome pasien.

\section{DAFTAR PUSTAKA}

Apold, J., \& Rydrych, D. (2012). Preventing Device-Related Pressure Ulcers Using 
Data to Guide Statewide Change. J Nurs Care Qual, Vol. 27, No. 1, pp. 28-34.

Baharestani, M. M., \& Ratliff, C. R. (2007). Pressure Ulcers in Neonates and Children: An NPUAP White Paper. Advances in Skin \& Wound Care, 20(4):208-220.

Black, J. M., \& Kalowes, P. (2016). Medical device-related pressure ulcers. Chronic Wound Care Management and Research, 3 91-99.

Black, J. M., Cuddigan, J. E., Walko, M. A., Didier, L. A., Lander, M. J., \& Kelpe, M. R. (2010). Medical device related pressure ulcers in hospitalized patients. Int Wound $J, \quad 7: 358-365$. doi: 10.1111/j.1742-481X.2010.00699.x.

Black, J., Alves, P., Brindle, C. T., Dealey, C., Santamaria, N., Call, E., et al. (2015). Use of wound dressings to enhance prevention of pressure ulcers caused by medical devices. Int Wound J., Jun;12(3):322-7. doi: 10.1111/iwj.12111.

Blume-Peytavi, U., Lavender, T., Jenerowicz, D., Ryumina, I., Stalder, J. F., Torrelo, A., et al. (2016). Recommendations from a European Roundtable Meeting on Best Practice Healthy Infant Skin Care. Pediatric Dermatology, Vol. 33 No. 3 311-321.

Curley, M. A., Hasbani, N. R., Quigley, S. M., Stellar, J. J., Pasek, T. A., Shelley, S. S., et al. (2018). Predicting Pressure Injury Risk in Pediatric Patients: The Braden QD Scale. J Pediatr, 192:189-95. doi.org/10.1016/j.jpeds.2017.09.045.

Fletcher, J. (2012). Device related pressure ulcers made easy. Wounds uk, 8(2):1-4.

Ghaffari, J., Abbaskhanian, A., \& Nazari, Z. (2014). Mortality Rate in Pediatric Intensive Care Unit (PICU): A Local Center Experience. International Journal of Pediatrics, Volume 2, Issue 3.2, August, Page 81-88. doi: 10.22038/IJP.2014.2956.

Hansen, R.-L., \& Fossum, M. (2016). Nursing documentation of pressure ulcers in nursing homes: comparison of record content and patient examinations. Nursing Open, 3(3), 159-167. https://doi.org/10.1002/nop2.47.

Kayser, S. A., VanGilder, C. A., Ayello, E. A., \& Lachenbruch, C. (2018). Prevalence and Analysis of Medical Device-Related
Pressure Injuries: Results from the International Pressure Ulcer Prevalence Survey. Adv Skin Wound Care, 31:27685.

Kudchadkar, S. R., Beers, M. C., Ascenzi, J. A., Jastaniah, E., \& Punjabi, N. M. (2016). Nurses' Perceptions of Pediatric Intensive Care Unit Environment and Work Experience After Transition to SinglePatient Rooms. AJCC, 25(5): e98-e107. 10.4037/ajcc2016463.

Lerner, J. C. (2014). Medical Devices' Role in Causing Pressure Ulcers. https://www. ecri.org/components/PSOCore/Pages/PS ONav0814.aspx: ECRI Institute.

Long, M. A., Ayer, M., \& Borchert, K. (2017). Medical Device-Related Pressure Injuries in Long-term Acute Care Hospital Setting. J Wound Ostomy Continence Nurs, Jul/Aug;44(4):325-330. doi: 10.1097/WON.0000000000000347.

Makic, M. B. (2015). Medical Device-Related Pressure Ulcers and Intensive Care Patients. Journal of PeriAnesthesia Nursing, Vol 30, No 4 (August): pp 336337.

McNichol, L., Lund, C., Rosen, \& Gray, M. (2013). Medical Adhesives and Patient Safety: State of the science. Consensus statements for the assessment, prevention and treatment of adhesive-related skin injuries. J Wound Ostomy Continence Nurs, 40(4): 365-80. doi: 10.1097/NOR.0b013e3182a39caf.

Mohammed, H. M., \& Hassan, M. S. (2015). Endotracheal tube securements: Effectiveness of three techniques among orally intubated patients. Egyptian Journal of Chest Diseases and Tuberculosis, 64(1), 183-196. https://doi.org/10.1016/j.ejcdt.2014.09.00 6.

Murray, J. S., Noonan, C., Quigley, S., \& Curley, M. A. (2013). Medical devicerelated hospital-acquired pressure ulcers in children: an integrative review. $J$ Pediatr Nurs, Nov-Dec;28(6):585-95. doi: 10.1016/j.pedn.2013.05.004.

National Pressure Ulcer Advisory Panel, European Pressure Ulcer Advisory Panel and Pan Pacific Pressure Injury Alliance. (2014). Prevention and Treatment of Pressure Ulcers: Quick Reference Guide. Perth, Australia: Cambridge Media. 
NPUAP. (2013). Best Practices for Prevention of Medical Device-Related Pressure Ulcers in Pediatric Population. Dipetik Juli 30, 2018, dari www.npuap.org: http: //www.npuap. org/wp-content/ uploads/ 2013/04/BestPractices-Pediatric1.pdf.

Randolph, A. G., Gonzales, C. A., Cortellini, L., \& Yeh, T. S. (2004). Growth of pediatric intensive care units in the United States from 1995 to 2001. $J$ Pediatr., Jun;144(6):792-8. doi: https://doi.org/10.1016/j.jpeds.2004.03.0 19.

Schober-Flores, C. (2012). Pressure ulcers in the pediatric population. Journal of the Dermatology Nurses' Association, 4(5), 295-306. https://doi.org/ 10.1097/JDN. 0b013e31826af5c6.

Sugiyono. (2013). Metode penelitian kuantitatif, kualitatif, dan $R$ \& $D$. Bandung: Alfabeta. 